\title{
BAURAN PROMOSI TELKOMSEL PADA CV. AKAR DAYA MANDIRI SINTANG
}

\author{
Evy Ratnasari \\ Fakultas Ilmu Sosial dan Ilmu Politik Universitas Kapuas \\ Jl. Y.C Oveang Oeray Nomor 92 Sintang
}

\begin{abstract}
Abstrak: Perusahaan telah melakukan promosi untuk meningkatkan penjualan produk telkomsel melalui media periklanan di radio dan media cetak serta menyediakan brosur-brosur tentang produk telkomsel. Selain menggunakan teknik periklanan, CV. Akar Daya Mandiri Sintang juga melakukan promosi dengan teknik penjualan tatap muka (personal selling). Teknik promosi dengan penjualan tatap muka ini dipandang lebih efektif dan efisien dari sisi biaya yang harus dikeluarkan, dengan hasil yang cukup menjanjikan, dikarenakan masyarakat langsung mendapat penjelasan tentang manfaat produk telkomsel dari agenagen produk telkomsel sebagai pelaksana penjualan tatap muka. Untuk meningkatkan pelanggan produk telkomsel, perusahaan juga melakukan promosi penjualan yang dilakukan oleh para agen penjualan. Promosi penjualan ini menyampaikan informasi tentang beberapa hal tentang kemudahan dan berbagai fasilitas yang diperoleh nasabah jika menjadi nasabah produk telkomsel. Pelaksanaan promosi dengan menggunakan teknik pemasaran langsung juga dilaksanakan oleh CV. Akar Daya Mandiri Sintang. Pelaksanaan pemasaran langsung yang telah dilakukan adalah melalui saluran telepon, internet, serta media sosial yang banyak memberikan informasi tentang produk-produk telkomsel dengan segala kelebihannya.
\end{abstract}

Kata Kunci : Bauran Promosi, Telkomsel, CV. Akar Daya Mandiri.

Teknologi komunikasi saat ini tidak hanya menjadi kebutuhan masyarakat umum tetapi juga menjadi ladang bisnis yang menjanjikan. Dengan adanya perkembangan bisnis operator selular yang terus meningkat setiap tahunnya. Di dukung pula dengan hadirnya telepon selular yang mampu dijangkau berbagai lapisan masyarakat dan pertumbuhan operator selular yang tergolong pesat di Indonesia.

Berkembang juga perusahaan distributor yang bekerja sama dengan perusahaan penyedia layanan telekomunikasi (provider) yang menawarkan dan menyalurkan produk-produk provider tersebut kepada konsumen. CV. Akar Daya Mandiri merupakan perusahaan distributor resmi produk Telkomsel yang didirikan pada tanggal 27 Juli 2008 secara nasional.

Perusahaan ini juga memiliki cabang di kota Sintang. Perusahaan yang berlokasi di Jalan Lintas Melawi Sintang ini merupakan salah satu perusahaan distributor yang bekerja sama dengan PT. Telekomunikasi Selular dalam menjual dan memasarkan produk Telkomsel, berupa kartu perdana Simpati di Sintang. Setiap perusahaan dituntut untuk siap menghadapi persaingan bisnis yang semakin ketat dengan perusahaan distributor lain untuk menghadapi globalisasi yang sering dikatakan era dunia tanpa batas. Dengan demikian lingkungan yang dihadapi suatu perusahaan juga akan menjadi semakin kompleks.

Kompleksitas persaingan yang dihadapi perusahaan tersebut akan memaksa setiap perusahaan untuk selalu berusaha meningkatkan pelayanannya terhadap konsumen. Persaingan bisnis yang bebas ini, syarat suatu perusahaan dapat sukses dalam persaingan adalah berusaha mencapai tujuan untuk menciptakan dan mempertahankan konsumen.

Setiap perusahaan tentu mempunyai misi dan strategi tersendiri agar tetap bertahan dan berkembang untuk menghadapi persaingan. Pemasaran membutuhkan lebih dari sekedar mengembangkan produk yang unggul, menawarkannya dengan harga yang menarik dan membuatnya mudah didapat oleh konsumen sasaran. Perusahaan juga harus mampu berkomunikasi dengan para konsumen nya dan para calon konsumen potensialnya mengenai produkproduk yang dipasarkan. Pemasaran adalah suatu kunci keberhasilan usahanya. Keberhasilan perusahaan sangat ditentukan oleh keberhasilan kegiatan pemasaran dari produk atau jasa yang dihasilkannya.

Penerapan konsep pemasaran yang tepat agar dapat menentukan strategi pasar dan strategi pemasaran yang mengarah pada sasaran yang ingin dicapai, yaitu meningkatkan penjualan. Faktor utama yang sangat mempengaruhi jalannya suatu manajemen marketing. Faktor-faktor tersebut yaitu produk, harga, daerah pemasaran dan promosi yang dilakukan oleh perusahaan itu sendiri. Promosi merupakan salah satu upaya yang digunakan oleh perusahaan untuk berkomunikasi, baik dengan konsumen nya maupun dengan calon konsumen nya, karena promosi itu sendiri sebenarnya adalah komunikasi. Sehingga perusahaan dapat lebih banyak menarik konsumen untuk membeli dan menggunakan produknya. 


\section{Bauran Promosi}

Kondisi persaingan bisnis industri telekomunikasi saat ini yang semakin ketat, sehingga perusahaan harus membuat strategi pemasaran untuk mempertahankan dan meraih pangsa pasar yang lebih tinggi serta meningkatkan pelayanannya terhadap konsumen. Menurut Kotler (2001:5) "pemasaran merupakan suatu proses kemasyarakatan yang mana individu dan kelompok mendapatkan apa yang dibutuhkan dan diinginkan melalui penciptaan, penawaran, dan pertukaran produk yang bernilai dengan pihak lain".

Promosi merupakan kegiatan Marketing Mix yang terakhir. Dalam kegiatan inisiatip bank berusaha untuk mempromosikan seluruh produk dan jasa yang dimilikinya baik langsung maupun tidak langsung. Menurut Kasmir (2004:176) "Promosi adalah kegiatan menawar". Menurut Swasta (1999:238) "Promotional mix adalah kombinasi strategi yang paling baik dari variabel periklanan, personal selling alat promosi yang lain, yang semuanya direncanakan untuk tujuan program penjualan".

Adapun definisi promosi menurut Stanton (2001:410) adalah: "Promosi is the element in an organization marketing mix that erves to inform, persuade, and remind the market of the organization or product. (Promosi adalah unsur dari bauran pemasaran suatu organisasi yang bertujuan memberitahukan, membujuk dan mengingatkan pasar dari organisasi/ produk)".

Bauran Promosi merupakan salah satu strategi pemasaran yang efektif dari bauran pemasaran. Untuk memasarkan suatu produk seorang pemasar harus mengembangkan program komunikasi yang efektif yang ditujukan kepada konsumen untuk mengkomunikasikan informasi yang ada dan dirancang untuk menghasilkan tindakan konsumen yang mengarah kepada keuntungan perusahaan. Menurut Stanton (2001:456) "bauran promosi adalah kombinasi dari penjualan perseorangan, periklanan, promosi penjualan, publisitas dan hubungan masyarakat".

Dari beberapa definisi tersebut di atas, dapat disimpulkan bahwa kegiatan promosi adalah bentuk-bentuk komunikasi yang digunakan perusahaan untuk memberikan informasi tentang adanya suatu produk beserta kelebihannya atau manfaatnya. Kemudian membujuk, mempengaruhi, dan meyakinkan konsumen agar mau membeli dan menggunakan produk tersebut serta mengingatkan konsumen sasaran tentang produk atau jasa yang ditawarkan sehingga akan meningkatkan volume penjualan barang/jasa.

\section{Periklanan (Advertising)}

Dengan melakukan kegiatan periklanan pada media cetak maupun elektronik, akan lebih menguntungkan bagi perusahaan, karena adanya kegiatan periklanan tersebut, maka produk yang di tawarkan oleh perusahaan semakin di kenal oleh masyarakat. Periklanan merupakan salah satu variabel dari bauran promosi. Untuk mencapai target penjualan yang telah di rencanakan oleh perusahaan, maka kegiatan promosi yang harus di lakukan oleh perusahaan adalah periklanan. Bentuk periklanan yang memperkenalkan produk melalui media cetak, media elektronik, brosur, dan lain-lain adalah periklanan. Definisi periklanan di kemukakan oleh Kotler dan Armstrong (2008:77) yaitu "Periklanan (advertising) adalah segala bentuk penyajian dan promosi bukan pribadi mengenai gagasan, barang, atau jasa yang dibayar oleh sponsor tertentu, di mana yang biasa jadi sponsor bukan hanya perusahaan saja tetapi juga dapat di lakukan oleh lembaga-lembaga lain, seperti perguruan tinggi, pemerintah, dan individu-individu".

Periklanan merupakan salah satu bentuk promosi yang tidak berhubungan langsung dengan konsumen, melainkan melalui media periklanan yang telah di rencanakan oleh perusahaan. Periklanan yang di lakukan oleh perusahaan harus menunjukkan gagasan dan pembuat iklan untuk memperkenalkan barang atau jasa kepada konsumen. Menurut Kotler dan Keller (2007:185) "Iklan adalah segala bentuk presentasi nonpribadi dan promosi gagasan, barang, atau jasa oleh sponsor tertentu yang harus dibayar".

Shimp (2008:209) menyatakan bahwa "iklan disebut efektif apabila iklan tersebut mencapai tujuan-tujuan yang ingin dicapai oleh pengiklan. Menurut Schultz dan Tannenbaum dalam Shimp (2008:209) "iklan yang efektif adalah iklan yang diciptakan untuk konsumen yang spesifik, memikirkan dan memahami kebutuhan konsumen , menekankan pada tindakan spesifik yang harus diambil oleh konsumen dan memahami bahwa orang-orang tidak membeli produk melainkan mereka membeli keuntungan dari produk tersebut".

\section{Penjualan Tatap Muka (personal selling)}

Personal selling juga merupakan salah satu bentuk kegiatan promosi. Personal selling merupakan kegiatan promosi yang di lakukan oleh perusahaan dengan melakukan tatap muka langsung dengan calon konsumen. Penjualan pribadi di lakukan oleh karyawan marketing perusahaan dengan mengunjungi ataupun di kunjungi oleh calon konsumen dan melakukan penjelasan secara langsung kepada konsumen mengenai produk yang di tawarkan. Definisi dari personal selling di kemukakan oleh Swastha dan Irawan (1990:350) sebagai berikut: "Personal selling adalah presentase lisan dalam suatu percakapan dengan 
satu calon pembeli atau lebih yang di tujukan untuk menciptakan penjualan". Jadi sasaran selling yang di lakukan oleh perusahaan adalah untuk menciptakan penjualan bagi perusahaan dengan melakukan presentasi secara lisan kepada calon konsumen baik secara individu maupun kelompok.

Tjiptono (2008:198) menyatakan bahwa "personal selling merupakan komunikasi langsung (tatap muka) antara penjual dan calon konsumen untuk memperkenalkan suatu produk kepada calon konsumen dan membentuk pemahaman terhadap suatu produk sehingga mereka kemudian akan mencoba dan membelinya". Personal selling berfungsi sebagai alat promosi dan media komunikasi untuk menginformasikan keberadaan dari suatu produk yang dihasilkan oleh perusahaan kepada konsumen. Perusahaan dapat menilai dan mengevaluasi sejauh mana konsumen mengenal dan mengetahui produk melalui pesan komunikasi yang telah disampaikan oleh kegiatan personal selling tersebut. Apalagi personal selling merupakan komunikasi langsung antara perusahaan yang diwakili tenaga penjual (marketer dan agen) yang diharapkan dapat dengan cepat mengtetahui respon konsumen dan menciptakan penjualan.

Personal selling digunakan sebagai salah satu alat promosi untuk berkomunikasi dengan konsumen potensial secara langsung. Penggunaan personal selling sangat beragam dari suatu organisasi ke organisasi lain. Pada beberapa perusahaan personal selling mungkin memainkan peran yang kecil dalam usaha promosi secara keseluruhan. Tetapi ada banyak perusahaan dimana personal selling digunakan bersama-sama dengan unsur promosi lain.

\section{Promosi penjualan (sales promotion)}

Promosi penjualan yang sering di lakukan oleh perusahaan adalah dengan memberikan insentif kepada karyawan marketing perusahaan maupun bukan karyawan perusahaan yang memberikan penjualan bagi produk yang di tawarkan oleh perusahaan. Salah satu bentuk promosi penjualan yang sering di lakukan oleh perusahaan adalah pemberian insentif kepada karyawan perusahaan yang melebihi target penjualan ataupun pemberian komisi kepada nonkaryawan perusahaan yang memberikan pendapatan bagi perusahaan. Defenisi promosi penjualan di kemukakan oleh Kotler dan Amstrong (2008:204) sebagai berikut "Promosi penjualan (sales promotion) adalah insentif jangka pendek untuk mendorong pembelian atau penjualan dari suatu produk atau jasa".

Jadi promosi penjualan merupakan insentif jangka pendek yang di lakukan oleh perusahaan untuk mendorong pembelian oleh konsumen atau penjualan dari suatu produk atau jasa yang di tawarkan oleh suatu organisasi perusahaan. Promosi penjualan di berikan kepada karyawan perusahaan yang mampu memasarkan produk yang di tawarkan kepada konsumen. Promosi penjualan meliputi pilihan sarana yang luas (kupon, kontes, potongan harga, premi, dan lainnya) semuanya mempunyai banyak kualitas unik. Semua sarana ini menarik perhatian konsumen, menawarkan insensif, dan bisa digunakan untuk mendramatisasi penawaran produk serta meningkatkan penjualan yang lesu.

Secara umum, daripada hanya menciptakan penjualan jangka pendek atau penukaran merek sementara, promosi penjualan harus memperkuat posisi produk dan

membangun hubungan konsumen jangka panjang. Sales promotion adalah bentuk persuasi langsung melalui penggunaan berbagai insentif yang dapat diatur untuk merangsang pembelian produk dengan segera dan/atau meningkatkan jumlah barang yang dibeli konsumen. Tujuan dari sales promotion sangat beraneka ragam. Melalui sales promotion, perusahaan dapat menarik konsumen baru, mempengaruhi konsumen nya untuk mencoba produk baru, mendorong konsumen membeli lebih banyak, menyerang aktivitas promosi pesaing, meningkatkan impulse buying (pembelian tanpa rencana sebelumnya), atau mengupayakan kerja sama yang lebih erat dengan pengecer.

\section{Pemasaran Langsung (Direct Marketing).}

Menurut Kotler dan Amstrong (2008:221) "pemasaran langsung (direct marketing) adalah hubungan langsung dengan konsumen individual yang ditargetkan secara hati-hati untuk meraih respon segera dan mencapai hubungan konsumen yang abadi”. Pemasar berkomunikasi langsung dengan konsumen, baik satu per satu dan berbasis interaktif. Disamping pembangunan merek dan hubungan konsumen, pemasar langsung biasanya mencari respons konsumen yang langsung, segera dan terukur.

Menurut Kotler (2001:242) "pemasaran langsung (direct marketing) terdiri atas komunikasi langsung dengan konsumen perorangan sasaran untuk memperoleh tanggapan segera". Dengan demikian, para pemasar langsung berkomunikasi langsung dengan konsumen, sering berdasarkan pertemuan satu-lawan-satu secara interaktif. Mereka benar-benar menyepadankan penawaran dan komunikasi pemasaran mereka dengan kebutuhan segmen sempit atau bahkan pembeli perorangan. Di luar pembangunan merek dan citra, mereka biasanya mencari tanggapan konsumen secara langsung, segera, dan terukur.

$$
\text { Menurut Saladin (2007:191) }
$$

"Pemasaran langsung adalah suatu sistem pemasaran yang menggunakan suatu media iklan 
atau lebih, guna mendapatkan respons dan/atau transaksi yang bisa diukur di suatu lokasi”. Menurut Kotler (2001:243) "pemasaran langsung memberikan manfaat kepada konsumen dalam berbagai cara. Konsumen melaporkan bahwa berbelanja dari rumah itu menyenangkan, mudah, dan tidak repot. Berbelanja dari rumah ini menghemat waktu dan memperkenalkan kepada mereka pilihan barang lebih beragam". Penjual juga memperoleh manfaat. Dengan teknologi sekarang, seorang pemasar langsung dapat memilih kelompok kecil atau bahkan konsumen perorangan, menyesuaikan tawarannya dengan kebutuhan dan keinginan khusus konsumen, dan mempromosikan tawaran ini melalui komunikasi yang telah disesuaikan dengan konsumen sasaran. Pemasaran langsung ini dapat membangun hubungan yang berkelanjutan dengan setiap konsumen .

\section{METODE PENELITIAN}

Penelitian ini menggunakan perspektif pendekatan kualitatif. Menurut Denzin dan Lincoln dalam Moleong (2006:5) menyatakan bahwa "penelitian kualitatif adalah penelitian yang menggunakan latar alamiah, dengan maksud menafsirkan fenomena yang terjadi dan dilakukan dengan jalan melibatkan berbagai metode yang ada". Adapun Bogdan dan Taylor dalam Moleong (2006:4) mendefinisikan "metodologi kualitatif sebagai prosedur penelitian yang menghasilkan data deskriptif berupa kata-kata tertulis atau lisan dari orang-orang dan perilaku yang dapat diamati”. Lokasi penelitian di CV. Akar Daya Mandiri Sintang

\section{HASIL PENELITIAN DAN PEMBAHASAN \\ Periklanan (advertising).}

Periklanan dapat dipandang sebagai penawaran terhadap suatu kelompok masyarakat baik secara lisan maupun dengan penglihatan tentang suatu produk, jasa ide, periklanan dapat menambah nilai pada suatu barang dengan memberi informasi kepada konsumen. Untuk itu ada beberapa pilihan media yang dapat digunakan untuk melakukan pengiklanan, antara lain melalui : surat kabar, majalah, radio, televisi, papan reklame.

Sudah dilakukan promosi oleh perusahaan dalam menjual produk telkomsel. Promosi yang dilakukan lebih banyak melalui sales promotion yang langsung ke counter-counter penjualan pulsa dengan menggunakan mobil toko (moko) perusahaan yang sangat menonjol dan mudah diingat.

Perusahaan telah melakukan promosi untuk meningkatkan penjualan produk telkomsel melalui media periklanan di radio dan media cetak serta menyediakan brosur-brosur tentang produk telkomsel. Namun promosi melalui iklan yang dilakukan masih belum maksimal, masih jarang didengar iklan melalui radio, maupun iklan melalui media cetak, kegiatan iklan ini hanya dilakukan pada waktu-waktu tertentu saja, seperti pada saat merayakan hari ulang tahun telkomsel.

Periklanan terbaik adalah yang dilakukan oleh konsumen yang puas, untuk kegiatan periklanan untuk memberikan informasi yang maksimal kepada masyarakat tentang manfaat ikut serta berproduk telkomsel perlu terus dijelaskan kepada masyarakat. Selain itu kepuasan masyarakat yang sudah menjadi konsumen produk telkomsel dalam memperoleh pelayanan dalam perusahaan merupakan sarana iklan yang efektif. Penyebaran informasi yang baik dari peserta produk telkomsel akan memberikan dampak positif terhadap keikutsertaan masyarakat untuk membeli produk telkomsel.

\section{Penjualan Personal (personal selling).}

Dalam penjualan tatap muka (personal selling) terjadi interaksi langsung, saling bertemu muka antar penjual dan pembeli. Komunikasi yang dilakukan kedua belah pihak bersifat individual dan dua arah sehingga penjual dapat langsung memperoleh tanggapan tentang keinginan pembeli. Penjualan tatap muka (Personal selling) merupakan sarana promosi dan penjualan dengan maksud menimbulkan transaksi jual beli, menimbulkan minat calon pembeli dan menimbulkan prefensi terhadap barang tertentu. Dengan personal selling sifatnya sangat luwes karena tenaga penjual dapat melihat secara langsung mengetahui keinginan, motif, perilaku dari calon konsumen.

Penjualan tatap muka dilakukan oleh TSA secara langsung ke konsumen dan juga ke counter-counter penjualan pulsa yang cukup banyak di dalam kota Sintang maupun di luar kota Sintang. Beberapa counter penjualan handphone dan pulsa yang menjadi konsumen pada CV Akar Daya Mandiri diantaranya adalah Total 88 Ponsel, Metro Ponsel, Digi Ponsel dan Seroja Ponsel.

Selain menggunakan teknik periklanan, CV. Akar Daya Mandiri Sintang juga melakukan promosi dengan teknik penjualan tatap muka (personal selling). Teknik promosi dengan penjualan tatap muka ini dipandang lebih efektif dan efisien dari sisi biaya yang harus dikeluarkan, dengan hasil yang cukup menjanjikan, dikarenakan masyarakat langsung mendapat penjelasan tentang manfaat produk telkomsel dari agen-agen produk telkomsel sebagai pelaksana penjualan tatap muka.

Tujuan pemasaran pada umumnya yaitu meningkatkan penjualan, menghasilkan laba dengan menawarkan kebutuhan yang memuaskan kepada pasar dalam jangka panjang. Dalam hal ini 
perusahaan memerlukan tenaga penjualan atau wiraniaga untuk melakukannya. Tugas-tugas yang mereka lakukan cukup luwes karena secara langsung dapat mengetahui keinginan, motivasi dan perilaku konsumen serta sekaligus melihat reaksi konsumen sehingga mereka dapat langsung melakukan penyesuaian seperlunya.

Dalam strategi pemasaran personal, setiap individu dituntut untuk mengerti, memahami dan menguasai secara praktis dan teoritis strategi pemasaran. Secara umum program yang dibuat dan diputuskan oleh perusahaan di implementasikan dalam strategi pemasaran yang meliputi produk, price, place dan promotion. Seorang manager pemasaran yang telah berpengalaman wajib mengetahui secara lebih mendalam dan melakukan dalam semua aktivitas pada proses pemasaran produk.

Dalam pelaksanaan kegiatan penjualan tatap muka terdapat beberapa tahap yang harus ditempuh oleh pihak penjual, yaitu : Persiapan sebelum penjualan, sebelum melakukan penjualan kegiatan yang dilakukan : Mempersiapkan tenaga penjual dengan memberikan pengertian tentang barang-barang yang dijual, pasar yang dituju, dan teknik-yeknik penjualan yang harus dilakukan. Harus mengetahui kemungkinan tentang motivasi dan perilaku dalam segmen pasar yang dituju.

Penentuan lokasi pembelian potensial. Dalam menentukan lokasi dapat digunakan datadata pembeli yang lalu maupun sekarang, dari sini dapat ditentukan karakteristik calon pembeli atau pembeli potensialnya. Penentuan karakteristik pembeli dapat dilakukan pula dengan segmentasi pasar. Dari konsumen yang ada dapat ditentukan pula konsumen yang sudah menggunakan produk pesaing.

Sebelum melakukan penjualan, penjual harus melakukan pendekatan pendahuluan terhadap pasar yaitu dengan cara : Mempelajari semua masalah tentang individu atau perusahaan yang dapat diharapkan sebagai pembelinya. Mengetahui produk atau merk apa yang sedang mereka gunakan dan bagaimana reaksinya. Mengumpulkan berbagai informasi untuk mendukung penawaran produknya kepada pembeli misalnya: kebiasaan membeli, kesukaan, dan sebagainya.

Pelaksanaan penjualan dapat dilakukan dengan melalui tahapan berikut: Diawali dengan suatu usaha memikat perhatian calon pembeli, Kemudian diusahakan mengetahui daya tarik dan minat mereka. Jika minat calon konsumen diikuti oleh minat dengan munculnya keinginan untuk membeli maka penjual tinggal merealisasikan penjualan produknya. Kegiatan penjualan tidak berakhir ada saat pesanan dari pembeli telah dipenuhi tetapi masih perlu dilanjutkan dengan memberikan pelayanan atau servis kepada mereka. Dalam tahap terakhir ini penjual harus berusaha mengatasi berbagai macam keluhan dan tanggapan yang kurang baik dari pembeli.

\section{Promosi Penjualan (sales promotion).}

Promosi Penjualan adalah sales promotion yaitu semua cara yang digunakan oleh agen pemasaran untuk menginformasikan, membujuk atau mempengaruhi pengguna akhir produk, tidak termasuk iklan, penjualan pribadi, dan publisitas; promosi penjualan merupakan alat bantu penjualan, termasuk pameran, bonus, kupon dan hadiah. Promosi penjualan merupakan bagian dari bauran promosi, dan saagat penting bagi kelangsungan hidup perusahaan dengan adanya promosi yang mendorong penjualan produk yang ditawarkan oleh perusahaan baik berupa barang atau jasa.

Promosi penjualan yang dilakukan oleh CV. Akar Daya Mandiri Sintang sudah cukup efektif, dimana berbagai metode promosi sudah dilakukan baik melalui penjualan langsung melalui TSA maupun melalui media cetak serta penjualan menggunakan mobil toko yang dimiliki. Konsumen CV. Akar Daya Mandiri Sintang sudah merasa terbantu dan puas dengan keberadaan perusahaan dalam memenuhi kebutuhan pemilik counter ponsel akan kebutuhan produk telkomsel.

Konsumen yang tidak puas terhadap penjualan terdahulu, dapat diperkecil melalui promosi penjualan yang baik, perangkat promosi penjualan merupakan suatu bahan promosi yang tersedia pada tempat pemberian yang memberikan informasi, membujuk dan mengingatkan konsumen akan barang dan jasa yang dipasarkan. Promosi penjualan yang dilakukan oleh penjual dapat dikelompokkan berdasar tujuan yang ingin dicapai. Pengelompokan tersebut adalah sebagai berikut: promosi yang bertujuan untuk mendorong atau merangsang konsumen untuk membeli, promosi penjualan yang bertujuan untuk merangsang atau mendorong pedagang grosir, pengecer, eksportir dan importir untuk memperdagangkan barang/ jasa dari sponsor. Promosi penjualan yang bertujuan untuk memotivasi armada penjualan. Promosi penjualan yang bertujuan untuk memperoleh konsumen baru, mempertahankan kontrak hubungan dengan konsumen, memperkenalkan produk baru, menjual lebih banyak kepada konsumen lama dan mendidik konsumen. Namun yang jelas apapun jenis kebutuhan yang akan diprogramkan untuk dipengaruhi, tetap pada perencanaan bagaimana agar perusahaan tetap eksis dan berkembang. Apalagi jika perusahaan tersebut mempunyai lini produk lebih dari satu macam. 
Pada saat ini promosi penjualan semakin berkembang, faktor-faktor yang mempengaruhi perkembangannya adalah semakin diterimanya aktivitas promosi penjualan untuk konsumen oleh para manajer pemasaran sebagai alat untuk meningkatkan penjualan, selain itu adanya perpindahan dana yang biasanya digunakan untuk iklan menjadi dana untuk promosi penjualan, karena meningkatnya jumlah ahli dibidang pemasaran penjualan serta banyaknya agen untuk promosi penjualan.

\section{Pemasaran Langsung (Direct Marketing).}

Pemasaran langsung adalah jenis kegiatan yang ditujukan untuk memperoleh tanggapan dari calon konsumen, baik melalui komunikasi telepon, surat, e-mail atau faks. Perencanaan adalah sebuah pendekatan professional yang dilakukan dalam direct marketing. Rencana yang dibuat tidak perlu terlalu rumit dan kompleks, namun dengan menganalisis pasar sasaran dan memilih pesan yang akan disampaikan serta menetapkan sasaran penjualannya.

Pelaksanaan promosi dengan menggunakan teknik pemasaran langsung juga dilaksanakan oleh CV. Akar Daya Mandiri Sintang. Pelaksanaan pemasaran langsung yang telah dilakukan adalah melalui saluran telepon, internet, serta media sosial yang banyak memberikan informasi tentang produk-produk telkomsel dengan segala kelebihannya. Kegiatan pemasaran langsung ini cukup memberikan dampak positif terhadap perkembangan konsumen produk telkomsel.

Salah satu peran penjualan langsung (direct marketing) adalah untuk membangun hubungan dengan konsumen, berkomunikasi secara langsung dengan konsumen. Awalnya direct mail menjadi alat utama, tapi seiring perkembangan teknologi, database telah diperkenalkan sebagai media lain yang dapat digunakan untuk berkomunikasi secara efektif dengan konsumen (individu). Semua elemen dari promotional mix dapat digunakan dengan direct marketing untuk mendukung dan membangun hubungan yang bermakna dengan konsumen dan anggota dari bermacam-macam jaringan stakeholder. Penjualan langsung (direct marketing) adalah sebuah strategi yang digunakan untuk membentuk dan meneruskan personal dan penengah dialog dengan konsumen. Hal ini seharusnya menjadi sebuah ukuran aktivitas.

Pemasaran langsung merupakan komunikasi langsung dengan konsumen individu yang dibidik secara seksama baik untuk memperoleh tanggapan segera maupun membina hubungan konsumen yang berlangsung lama. Di dalam pemasaran langsung biasanya menggunakan saluran-saluran langsung ke konsumen (Consumer direct) untuk menjangkau dan menyerahkan barang dan jasa kepada konsumen tanpa menggunakan perantara pemasaran. Saluransaluran ini mencakup surat langsung, catalog, telemarketing, tv interaktif, situs internet, dan lainlain, namun belum semua saluran tersebut digunakan oleh CV. Akar Daya Mandiri Sintang.

Pemasaran langsung merupakan salah satu cara yang tumbuh paling pesat untuk melayani konsumen. Saat ini terdapat banyak pemasar langsung menggunakan pemasaran langsung untuk membina hubungan jangka pendek dengan konsumen .. mereka mengirim kartu ulang tahun, bahan-bahan informasi, atau bingkisan kecil bagi konsumen tertentu. Para pemasar melakukan pemasaran langsung untuk meningkatkan produktivitas satuan penjualan. Selain itu perusahaan juga berupaya untuk menggantikan unit-unit penjualan berbasis pos dan telepon untuk mengurangi biaya penjualan lapangan.

Keberhasilan pemasaran dengan metode direct marketing juga sangat ditentukan oleh cara memilih daftar nama dan alamat daftar nama dan alamat orang-orang yang akan dikirimi surat tawaran. Daftar nama dan alamat bukanlah sekadar sarana untuk meraih pasar karena sesungguhnya daftar nama dan alamat adalah pasar itu sendiri. Kejelian dalam memilih daftar nama dan alamat adalah faktor terpenting yang menentukan besar kecilnya respons dari penerima yang menjadi sasaran.

\section{KESIMPULAN DAN SARAN}

Perusahaan telah melakukan promosi untuk meningkatkan penjualan produk telkomsel melalui media periklanan di radio dan media cetak serta menyediakan brosur-brosur tentang produk telkomsel. Selain menggunakan teknik periklanan, CV. Akar Daya Mandiri Sintang juga melakukan promosi dengan teknik penjualan tatap muka (personal selling). Teknik promosi dengan penjualan tatap muka ini dipandang lebih efektif dan efisien dari sisi biaya yang harus dikeluarkan, dengan hasil yang cukup menjanjikan, dikarenakan masyarakat langsung mendapat penjelasan tentang manfaat produk telkomsel dari agen-agen produk telkomsel sebagai pelaksana penjualan tatap muka. Untuk meningkatkan konsumen produk telkomsel, perusahaan juga melakukan promosi penjualan yang dilakukan oleh para agen penjualan. Promosi penjualan ini menyampaikan informasi tentang beberapa hal tentang kemudahan dan berbagai fasilitas yang diperoleh nasabah jika menjadi nasabah produk telkomsel. Pelaksanaan promosi dengan menggunakan teknik pemasaran langsung juga dilaksanakan oleh CV. Akar Daya Mandiri Sintang. Pelaksanaan pemasaran langsung yang 
telah dilakukan adalah melalui saluran telepon, internet, serta media sosial yang banyak memberikan informasi tentang produk-produk telkomsel dengan segala kelebihannya.

Terus mempertahankan strategi pemasaran yang sudah baik dan berupaya meningkatkannya. Lebih meningkatkan promosi melalui media cetak dan media social. Lebih gencar lagi melakukan promosi penjualan melalui penjualan tatap muka secara langsung ke konsumen. Menambah tenaga-tenaga penjualan agar lebih banyak menjangkau masyarakat sebagai pengguna telkomsel.

\section{DAFTAR PUSTAKA}

Alma. B. 2007. Manajemen Pemasaran Dan Pemasaran Jasa. Bandung: Alfabeta.

Arikunto, S. 1998. Prosedur Penelitian Suatu Pendekatan Praktis. Jakarta: Rineka Cipta.

Asri, M. 2003. Anggaran Perusahaan, Buku 1. Yogyakarta: Penerbit BPFE.

Assauri. S. 2004. Manajemen Pemasaran. Jakarta: Raja Grafindo Persada.

Dharmesta dan Irawan, 2005. Manajemen Pemasaran Modern. Edisi Kedua. Yogyakarta : Liberty

Kotler, P. 2001. Manajemen Pemasaran di Indonesia : Analisis, Perencanaan, Implementasi dan Pengendalian. Jakarta: Salemba Empat.

Kotler. P. And Armstrong. G. 2008. Dasar-dasar Pemasaran (edisi kesembilan). Jakarta: PT. Indeks.

Kotler, P. And Keller. K. 2007. Manajemen Pemasaran (edisi duabelas). Jakarta: PT. Indeks.

Lupiyoadi. R. 2008. Manajemen Pemasaran Jasa, Edisi 2. Jakarta: Salemba Empat.

Moleong, L.J. 2006. Metodologi Penelitian Kuantitatif. Bandung: PT. Remaja Rosdakarya.

Narbuko, C \& Achmadi, A. 2003. Metodologi Penelitian. Jakarta: Bumi Aksara.

Nazir, M. 1999. Metode Penelitian. Jakarta: Ghalia Indonesia.
Nawawi, dan Martini. 1991. Instrumen Penelitian Bidang Sosial. Yogyakarta: Gajah Mada University Press.

Saladin. D. 2007. Intisari Pemasaran dan UnsurUnsur Pemasaran. Cetakan Keempat. Bandung: Linda Karya.

Shimp. T. 2008. Periklanan Promosi dan Aspek Pertambahan Komunikasi Pemasaran Terpadu. Edisi Kelima. AlihBahasa Revyani Sjahrial dan Dyah Anikasari, Jakarta: Erlangga.

Stanton, J.W. 2001. Prinsip Pemasaran. Jakarta: Erlangga.

Sugiyono. 2010. Metode Penelitian Kuantitatif Kualitatif \& RND. Bandung: Alfabeta.

Suyanto. M. 2008. Strategi Perancangan Iklan televisi Perusahaan Top

Dunia.Yogyakarta: Andi.

Swasta, 1999. Azaz Marketing. Yokyakarta: Liberty.

Swastha, B. dan Irawan. 1990. Manajemen Pemasaran Modern. Yogyakarta: Liberty. Tiptono. F. 2008. Strategi Pemasaran. Yogyakarta: CV Andi 